\title{
Physical Activity and Exercise for Older People Living with HIV: A Scoping Review
}

\section{Levin Chetty (D) \\ Saul Cobbing \\ Verusia Chetty (ID}

School of Health Sciences, University of KwaZulu-Natal, Durban, South Africa

\section{Video abstract}

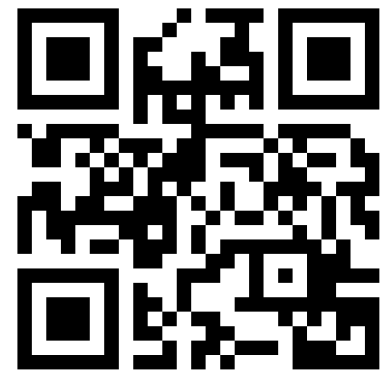

Point your SmartPhone at the code above. If you have a $Q R$ code reader the video abstract will appear. Or use: https://youtu.be/0t7lznceD_g

Correspondence: Levin Chetty Discipline of Physiotherapy, School of Health Sciences, University of KwaZuluNatal, Private Bag X5400I, Durban, 4000 Tel +273I 2608949

$\mathrm{Fax}+27312608106$

Email chettyle@ukzn.ac.za
Introduction: Improvements in physical, mental, and overall quality of life are well documented in younger HIV populations who exercise. Exercise guidelines exist for younger HIV populations, but none for older people living with HIV (OPLWH), especially 50 years of age and older. Our aim was to map the existing literature on the effects of exercise and physical activity prescriptions for OPLWH.

Methods: We conducted a scoping review using the methodological framework proposed by the Joanna Briggs Institute. Online searches on five research databases yielded 503 published articles. Fifteen studies met the study's inclusion criteria.

Results: The most commonly used parameters of exercise included aerobic and strength training, as well as a combination of both. The physical, psychological and Quality of Life (QoL) impact of physical activity and its effect on OPLWH is evidently beneficial. Overall, a positive correlation between exercise and physical, mental and functional status was observed. No adverse side effects, or safety and efficacy concerns, during the use of exercise were reported.

Conclusion: This review confirms the dearth of evidence on physical activity and exercise in the context of OPLWH. Of greater concern is the fact that there were no studies conducted in sub-Saharan Africa, the global region with by far the highest HIV burden.

Keywords: HIV, physical activity, exercise, geriatrics, health

\section{Introduction}

With the advent and continual development of antiretroviral therapy (ART), dramatic declines in morbidity and mortality rates associated with the human immunodeficiency virus (HIV) across the globe have been observed. ${ }^{1}$ With major medical successes and advances in ART, people living with HIV (PLHIV) are living longer. ${ }^{2}$ PLHIV may survive for 30 to 50 years, post-acute infection. ${ }^{3}$ Estimates further suggest that ART intervention at 20 years of age is likely to add 26.7 years to life expectancy; while ART intervention at age 35 is believed to increase life expectancy by 27.9 years; and at age 50, an additional 24 years is to be expected. ${ }^{4}$ Nearly half of PLHIV are over the age of 50 years old, and by the year 2030 this figure is expected to increase to $70 \% .^{5}$ In sub-Saharan Africa, which is acknowledged as the epicenter of the burden, $15 \%$ of the population living with HIV are aged at least 50 years and older, and predictive modeling suggests that by the year 2040 this ratio will increase to $27 \%$. By inference, the number of older people living with HIV (OPLWH) will increase to 9.1 million. $^{6}$

Ageing with HIV has become the latest challenge in the HIV phenomenon as ART prolongs survival, but the majority of HIV research only includes adults up to 
the age of $49 .{ }^{7}$ Older people living with HIV (OPLWH) are facing various challenges that continue to influence their physical, mental and social health. While some may continue to live without the need for additional healthcare, financial services or social care, there is a major cohort of OPLWH who now, and in the future, may require significant levels of support, including healthcare and rehabilitation. With shrinking public health and social care budgets, the future is very uncertain across the globe, especially in low-to-middle-income countries. ${ }^{8}$ While ART has increased life expectancy in PLHIV, it is unfortunately also associated with a constellation of health problems and physical impairments, such as sarcopenia and peripheral neuropathies, which influence functional activity. ${ }^{9}$ Functional limitations and disabilities in OPLWH are not merely associated with the disease itself, but also with the secondary effects of ART. ${ }^{10}$ Further investigations suggest that both HIV infection and ART are associated with a range of chronic conditions that can manifest in OPLWH. These conditions include cardiovascular disease, diabetes and osteoporosis, and can present additional challenges with respect to their management. ${ }^{11}$

Simply stated, OPLWH are now living longer but are at a greater risk of developing various health complications, the consequence of living with a viral infection, exposure to medications that carry their own toxicity and side effects, and the natural effects of aging on the immune system. ${ }^{12}$ Faster rates of decline in functional status and physical performance levels are often observed in PLHIV, in addition to reduced muscle mass and strength (sarcopenia), and bone mineral density, as they get older. ${ }^{13,14}$ Increased physical activity levels and exercise are recommended to reduce functional impairment in OPLWH. ${ }^{15}$ In addition to serological and physical changes, mental and psychological disorders may also manifest in HIV populations. ${ }^{16}$ Regular exercise over a prolonged period of time has been proven to be beneficial in addressing mental health issues and improving psychological functioning in PLHIV. ${ }^{17}$ Aerobic exercise alone has the capacity to reduce the severity of depressive symptoms, while a combination of aerobic and resistance training has been shown to considerably decrease anxiety levels in PLHIV. $^{18,19}$

The role of regular exercise and physical activity in older HIV-negative populations has been extensively researched. Improved cardiovascular and neuropsychological health, and decreased rates of osteoporosis and osteoarthritis, together a lower risk of diabetes, are some of the associated benefits. ${ }^{20-22}$ Resistance exercise on its own can improve muscle mass and strength, and functional capacity, as well as positively influencing energy requirements; while a combination of aerobic and resistance activities can help to reduce fatigue levels and improve overall quality of life in aging populations. ${ }^{23-25}$ Improved functional fitness levels in the aged are also reported, following participation in progressive, multifaceted group exercise programmes, just twice a week over a 12-week period. ${ }^{26}$ From an HIV viewpoint, research suggests that, while physical activity may not have a positive impact on reducing viral replication or improving the immune systems of PLHIV, it can elicit improvements in cardiorespiratory fitness, strength, body composition, and overall quality of life. ${ }^{27}$ Aerobic exercise has been shown to improve pulmonary functions, such as forced expiratory volume $\left(\mathrm{FEV}_{1}\right)$, forced vital capacity (FVC) and peak expiratory flow rate (PEFR), whilst also alleviating respiratory and depressive symptoms in younger HIV populations. ${ }^{28}$ A combination of aerobic and resistance training aids in maintaining lean body mass, while also controlling cholesterol and triglyceride indices by reducing body fat mass and body fat percentage. ${ }^{29}$ Improved neurocognitive and everyday functioning have been observed in younger PLHIV who participate in regular physical activity regimes. ${ }^{30,31}$

Exercise and physical activity are also considered to be safe for PLHIV and should therefore be included as part of their comprehensive medical management, especially as they age with HIV. ${ }^{32,33}$ Although general physical activity guidelines exist for PLHIV, there are no clear guidelines for prescribing physical activity and exercise that is applicable to OPLWH; especially those who are 50 years of age and older. $^{34,35}$ The aim of this scoping review was to map existing literature on the effect of prescribing exercise and physical activity for OPLWH.

\section{Methods \\ Design}

A scoping review was conducted following the methodological framework suggested by Arksey and O'Malley. ${ }^{36}$ In accordance with this framework, the following five steps were used to conduct the scoping review: (1) identification of the research question; (2) identification of relevant studies; (3) selection of eligible research articles; (4) extraction and charting of the data; and (5) collating, summarizing, and reporting the results. The protocol for the scoping review 
was registered on the Open Science Framework platform (registration ID: https://osf.io/728kp/) ${ }^{37}$.

\section{Identification of the Research Question}

The overall study aim underpinning this scoping review was: "What are the effects of prescribed exercise and/or physical activity on OPLWH?" The research questions were identified as follows:

1. What are the physical health-related outcomes of exercise or physical activity in OPLWH?

2. What are the psychological or mental health-related outcomes of exercise and physical activity in OPLWH?

3. How does exercise or physical activity influence quality of life (QoL) in OPLWH?

4. What are the exercise recommendations for OPLWH?

\section{Information Sources and Search Strategy}

The identification of studies relevant to this scoping review was achieved through the utilization of the search strategy recommended by the Joanna Briggs Institute. ${ }^{38}$ A search for literature was conducted on the following electronic databases: PubMed; Google Scholar; Cinahl; MEDLINE and Cochrane Library. No date limits were imposed on the search strategy. The Boolean terms "AND," "OR," and "NOT" were used to separate keywords. Further potentially relevant studies were identified by conducting a search of the references included in articles and searches on websites such as the World Health Organization (WHO) and the Directory of Research on Ageing. A health sciences librarian employed by the University of KwaZulu-Natal library services was consulted throughout the search process.

\section{Selection of Eligible Studies}

The population concept context (PPC) framework was used to align the selection of appropriate research articles with the research question/s. All articles or studies had to meet the following inclusion criteria:

- older people living with HIV ( $\geq 50$ years of age);

- published in a peer-reviewed journal; and

- articles written in English.

Articles were excluded for the following reasons:

- studies where full-text articles could not be obtained; and
- articles that were considered to be commentaries or opinion pieces.

The selected articles were then assessed in greater depth to ensure that they included a measurement or focus on specific dimensions of physical activity and exercise in the proposed conceptual framework (eg, quality of life, functional status, activities of daily living), as well as a description of the intervention used (eg, aerobic exercise; anaerobic exercise; strengthening, flexibility, resistance, and balance activities). Eligible articles were uploaded into the Endnote Version 9 software program for Windows 10. This citation manager program was used to identify and remove all duplicate articles. The titles and abstracts of eligible articles were screened by two reviewers to ensure that the selected studies were related to the research objectives. Excluded citations were reviewed by a third reviewer and included if necessary. All reviewers utilized the free web and the mobile application, Rayyan, to screen titles and abstracts. The use of this application easily allowed a blind peer reviewer option to minimize bias. Full-text screening of the selected articles was then conducted by two reviewers independently. Significant discrepancies and disagreements between both reviewers were resolved through discussion and if there was still no agreement, the third reviewer was employed to ensure consensus on the final decision. Cohen's kappa coefficient was used to assess the agreement between reviewers. Following this rigorous selection process, fifteen academic publications were eventually identified and included in this scoping review. Figure 1 represents a Preferred Reporting Items for Systematic Reviews and Meta-Analyses (PRISMA) flow diagram, depicting the process of searching and selecting the research publications.

\section{Charting the Data}

Following the selection of relevant studies, data from each eligible study was extracted and recorded in a standardized data abstraction tool designed for this scoping review. The tool helped to record the relevant evidence for key study characteristics and detailed information for each study, which included the following:

- study characteristics: study design, year of publication, journal, sample size and setting, country of origin, aim/objective of the study; 


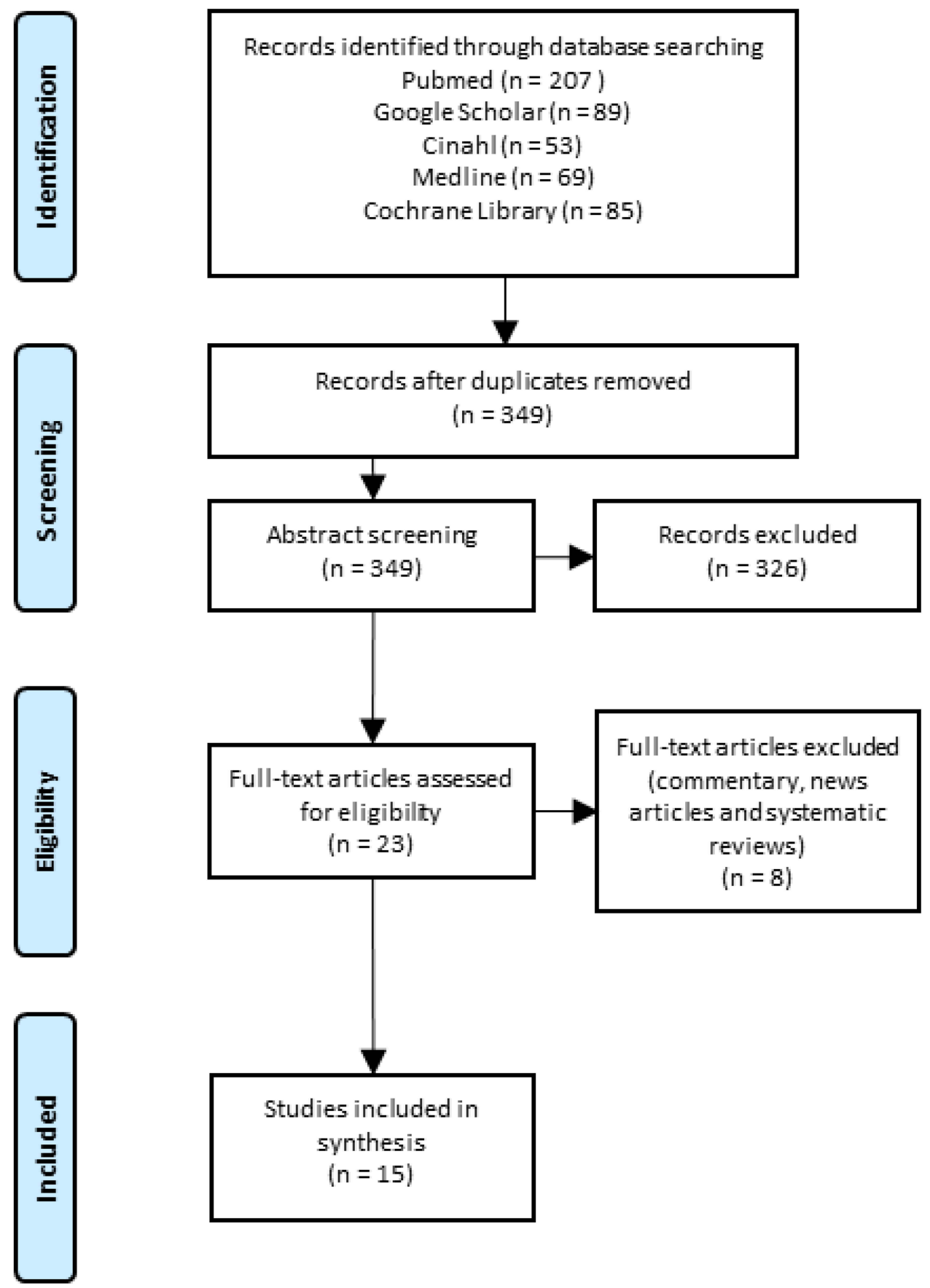

Figure I PRISMA flow diagram for the scoping review process.

Notes: PRISMA figure adapted from Moher D, Liberati A, Altman D, Tetzlaff J, et al. The PRISMA statement for reporting systematic reviews and meta-analyses of studies that evaluate health care interventions: explanation and elaboration. Journal of clinical epidemiology. 2009;62(10). Creative Commons. ${ }^{58}$

- participant characteristics: population sampled, age (mean with standard deviation, range), and gender (percentage of male/female participants);

- interventions: physical activity and exercise (type and duration or intensity);

- outcomes (findings relevant to study objectives); and

- key relevant findings and conclusions.

\section{Collating, Summarizing and Reporting the} Results

Based on the main research objectives of this scoping review, the relevant articles were contextualized in relation to the following four research domains: physical healthrelated outcomes of exercise or physical activity in OPLWH; mental health-related outcomes of exercise or 
physical activity in OPLWH; the impact of exercise or physical activity on functional status levels in OPLWH; and finally, structured exercise prescription recommendations, if any, for OPLWH. The research domains, publishing dates, journal language, authors' affiliations, and methodological characteristics were all analyzed. The quality of the selected studies from the search strategy was further appraised using the Mixed Methods Appraisal Tool (MMAT) version 2018. ${ }^{39}$

\section{Results}

\section{Characteristics of Published Studies}

The rigorous search process resulted in the final selection of fifteen articles that were eligible for this scoping review. Details of the fifteen articles included for analysis and write-up are reflected in Table 1. Six articles used a randomized control trial methodology. Three articles used a quasi-experimental research design. Two articles used a case study approach. A further two articles employed a cross-sectional study design; while the last two studies utilized a focus group discussion and a prospective nonrandomized study design, respectively. All fifteen studies were conducted in urban settings. Ten of the studies were conducted in the developed world (United States of America) and four of them in the developing world (Brazil and China); while one cross-sectional study comprised a sample population from both a developed and a developing country (United States of America and Thailand). All the studies included participants who were older than 50 years of age.

\section{Exercise and Physical Health and Function}

The majority of the research articles focused on the effects of exercise and physical health. The most commonly used parameters of exercise included aerobic and strength training, as well as a combination of both, whilst only one study focused on balance and mobility exercises for OPLWH. Two studies $(8,13)$ focused solely on aerobic activity for this population. Webel et al (2019) used a cross-sectional study design to determine the relationship between physical activity and cardiorespiratory fitness among PLHIV and reported that a large, diverse sample of participants engaged in low amounts of physical activity. Among women living with HIV, engaging in vigorous physical activity was associated with improved cardiorespiratory function. Oursler et al (2018) suggested, after the use of a randomized control trial, that moderate-to-high intensity aerobic exercise has the capacity to increase endurance and ambulatory function in older HIV-infected men. However, increased cardiorespiratory fitness was only observed with high intensity aerobic exercise.

Two studies focused on strength training $(1,2)$. De Souza et al (2008) reported substantial strength gains in every patient regardless of their age, gender, baseline stage of HIV infection, or the presence of any HIV/AIDS associated morbidity. De Souza et al (2011) reaffirmed the benefits of progressive resistance exercise in safely improving strength levels in OPLWH, allowing them to achieve performance and physical fitness levels observed among otherwise healthy controls. Participants in both studies participated in a progressive resistance training programme twice a week over a twelve-month period. One study evaluated the effectiveness and acceptability of a novel game-based training programme in ameliorating some aspects of frailty in OPLWH (6). The intervention was conducted twice a week for six weeks, with patients performing balance exercises such as weight shifting, ankle reaching and obstacle crossing. The results of this intervention showed promise in improving balance and mobility, whilst also requiring OPLWH to be more active.

The most commonly reported length of exercise programmes for aerobic exercise, resistance exercise, or both, ranged from two weeks to twenty-four weeks, with the exception of De Souza et al (2008) (1) and De Souza et al (2011) (2), who investigated a resistance programme lasting 12 months. An exercise frequency of two to three times per week was consistently reported in all the research studies and was found to be beneficial. Safeek et al (2018) (9) described the correlation between low levels of physical activity and poor physical functioning in OPLWH. The authors stressed the need to promote physical activity in this population, primarily because a large proportion of their cohort accumulated substantial sedentary time.

Johs et al (2019) (12) employed focus group discussions to determine differences in perceived barriers and benefits of exercise among OPLWH. Exercisers cited positive reinforcement, positive mood change and increased energy as benefits. Interpersonal benefits of exercise were also reported twice as often by exercisers than by nonexercisers. Age-appropriate activities were identified by non-exercisers as a feature of an ideal exercise environment. Overall, a positive correlation between exercise, be it aerobic, resistance, or both, and physical health (strength and cardiorespiratory) parameters, was observed in the selected 
Table I Study Characteristics

\begin{tabular}{|c|c|c|c|c|c|c|}
\hline & Author & Title & $\begin{array}{l}\text { Study } \\
\text { Design }\end{array}$ & $\begin{array}{l}\text { Study } \\
\text { Setting }\end{array}$ & Participants & Relevant Findings \\
\hline 1 & $\begin{array}{l}\text { De Souza } \\
\text { et al. } \\
(2008)^{44}\end{array}$ & $\begin{array}{l}\text { Progressive resistance training in } \\
\text { elderly HIV-positive patients: } \\
\text { Does it work? }\end{array}$ & $\begin{array}{l}\text { Case study } \\
\text { design }\end{array}$ & $\begin{array}{l}\text { Brazil } \\
\text { (Urban) }\end{array}$ & $N=11$ & $\begin{array}{l}\text { Resistance training increased strength, improved } \\
\text { physical fitness, reduced upper and lower limb } \\
\text { skinfolds, and was associated with an improvement in } \\
\text { the CD4+ and CD4+/CD8+ counts in older HIV- } \\
\text { positive patients, without significant side effects. }\end{array}$ \\
\hline 2 & $\begin{array}{l}\text { De Souza } \\
\text { et al. } \\
(20 \mathrm{II})^{45}\end{array}$ & $\begin{array}{l}\text { Effect of progressive resistance } \\
\text { exercise on strength evolution of } \\
\text { elderly patients living with HIV } \\
\text { compared to healthy controls. }\end{array}$ & $\begin{array}{l}\text { Prospective, } \\
\text { non- } \\
\text { randomized } \\
\text { study }\end{array}$ & $\begin{array}{l}\text { Brazil } \\
\text { (Urban) }\end{array}$ & $\begin{array}{l}\mathrm{N}=32(\text { Control=2I, } \\
\text { Intervention }=\mathrm{I} \mathrm{I})\end{array}$ & $\begin{array}{l}\text { Resistance exercise safely increased the strength of } \\
\text { older patients living with HIV, allowing them to } \\
\text { achieve performance levels similar to healthy } \\
\text { controls. Improved fasting glucose and lipid levels } \\
\text { after the one-year training programme were also } \\
\text { observed. }\end{array}$ \\
\hline 3 & $\begin{array}{l}\text { de Araújo } \\
\text { et al. } \\
(2014)^{46}\end{array}$ & $\begin{array}{l}\text { Influence of physical exercise on } \\
\text { practice morphofunctional } \\
\text { standards, immune function and } \\
\text { quality of elderly with AIDS: } \\
\text { a case study. }\end{array}$ & $\begin{array}{l}\text { Case study } \\
\text { design }\end{array}$ & $\begin{array}{l}\text { Brazil } \\
\text { (Urban) }\end{array}$ & $N=4$ & $\begin{array}{l}\text { A I6-week exercise intervention programme, consisting } \\
\text { of aerobic and resistance training, promoted } \\
\text { improvements in the components of morphofunctional } \\
\text { standards, with emphasis on flexibility and muscle } \\
\text { strength, as well as possible changes in markers of } \\
\text { immune function and quality of life domains. }\end{array}$ \\
\hline 4 & $\begin{array}{l}\text { Fazeli } \\
\text { et al. } \\
(2015)^{31}\end{array}$ & $\begin{array}{l}\text { Physical activity is associated } \\
\text { with better neurocognitive and } \\
\text { everyday functioning among } \\
\text { older adults with HIV disease. }\end{array}$ & $\begin{array}{l}\text { Cross- } \\
\text { sectional } \\
\text { study }\end{array}$ & $\begin{array}{l}\text { United } \\
\text { States of } \\
\text { America } \\
\text { (Urban) }\end{array}$ & $N=100$ & $\begin{array}{l}\text { Higher levels of moderate PA were associated with } \\
\text { lower chances of neurocognitive impairment }(\mathrm{NCl}) \text {. } \\
\text { Higher levels of moderate PA were also associated } \\
\text { with lower chances of dependence on instruments } \\
\text { for the activities of daily living (IADL). Follow-up } \\
\text { analysis showed those with both } \mathrm{NCl} \text { and IADL } \\
\text { dependence had lower moderate PA than those with } \\
\text { neither. }\end{array}$ \\
\hline 5 & $\begin{array}{l}\text { Shah et al. } \\
(2016)^{47}\end{array}$ & $\begin{array}{l}\text { Enhancing physical function in } \\
\text { HIV-infected older adults - } \\
\text { a randomized controlled clinical } \\
\text { trial. }\end{array}$ & $\begin{array}{l}\text { Randomized } \\
\text { control trial }\end{array}$ & $\begin{array}{l}\text { United } \\
\text { States of } \\
\text { America } \\
\text { (Urban) }\end{array}$ & $\begin{array}{l}\mathrm{N}=67 \text { (Control=34, } \\
\text { Intervention }=33 \text { ) }\end{array}$ & $\begin{array}{l}\text { Overall physical performance, gait speed, } \\
\text { measurements of endurance and strength, and levels of } \\
\text { physical activity, improved in the treatment group } \\
\text { compared to the control group. Measurements of } \\
\text { autonomous regulation and measurements of } \\
\text { depression and QoL improved significantly in the } \\
\text { treatment group compared to the control group. } \\
\text { Across the groups, improvement in intrinsic regulation } \\
\text { and QoL correlated with an improvement in physical } \\
\text { function. }\end{array}$ \\
\hline 6 & $\begin{array}{l}\text { Veeravelli } \\
\text { et al. } \\
(2016)^{48}\end{array}$ & $\begin{array}{l}\text { Exergaming in older people living } \\
\text { with HIV improves balance, } \\
\text { mobility and ameliorates some } \\
\text { aspects of frailty. }\end{array}$ & $\begin{array}{l}\text { Quasi- } \\
\text { experimental } \\
\text { design }\end{array}$ & $\begin{array}{l}\text { United } \\
\text { States of } \\
\text { America } \\
\text { (Urban) }\end{array}$ & $N=10$ & $\begin{array}{l}\text { The intervention showed improvements in balance } \\
\text { and mobility, while requiring older people living with } \\
\text { HIV to be more active. Exergaming can be performed } \\
\text { at home and may have long-term as well as short- } \\
\text { term benefits for ameliorating frailty associated with } \\
\text { HIV infection. }\end{array}$ \\
\hline 7 & $\begin{array}{l}\text { Erlandson } \\
\text { et al. } \\
(2018)^{49}\end{array}$ & $\begin{array}{l}\text { Improvements in physical } \\
\text { function, with moderate or high- } \\
\text { intensity exercise among older } \\
\text { adults with or without HIV } \\
\text { infection. }\end{array}$ & $\begin{array}{l}\text { Randomized } \\
\text { control trial }\end{array}$ & $\begin{array}{l}\text { United } \\
\text { States of } \\
\text { America } \\
\text { (Urban) }\end{array}$ & $\begin{array}{l}\mathrm{N}=69 \text { (Control=37, } \\
\text { Intervention }=32)\end{array}$ & $\begin{array}{l}\text { PLWH had significantly poorer physical function } \\
\text { across nearly all baseline measurements. Both groups } \\
\text { showed significant improvements in all function } \\
\text { measurements. An interaction between exercise } \\
\text { intensity and HIV serostatus was significant for } \\
\text { measurements of strength. Randomly selected PLWH } \\
\text { participating in high-intensity exercise gained } \\
\text { significantly more strength than those participating in } \\
\text { moderate-intensity activity. Controls had similar } \\
\text { gains, regardless of intensity. }\end{array}$ \\
\hline
\end{tabular}

(Continued) 
Table I (Continued).

\begin{tabular}{|c|c|c|c|c|c|c|}
\hline & Author & Title & $\begin{array}{l}\text { Study } \\
\text { Design }\end{array}$ & $\begin{array}{l}\text { Study } \\
\text { Setting }\end{array}$ & Participants & Relevant Findings \\
\hline 8 & $\begin{array}{l}\text { Oursler } \\
\text { et al. } \\
(2018)^{50}\end{array}$ & $\begin{array}{l}\text { A randomized, pilot aerobic } \\
\text { exercise trial in older HIV- } \\
\text { infected men: insights into } \\
\text { strategies for successful aging } \\
\text { with HIV. }\end{array}$ & $\begin{array}{l}\text { Randomized } \\
\text { control trial }\end{array}$ & $\begin{array}{l}\text { United } \\
\text { States of } \\
\text { America } \\
\text { (Urban) }\end{array}$ & $\begin{array}{l}\mathrm{N}=22(\text { Mod-AEX }= \\
\mathrm{II} ; \text { High-AEX=II) }\end{array}$ & $\begin{array}{l}\text { Moderate- to high-intensity aerobic exercise in older } \\
\text { HIV-infected men increases endurance and ambulatory } \\
\text { function. However, increased cardiorespiratory fitness } \\
\text { was only observed with high-intensity aerobic exercise. }\end{array}$ \\
\hline 9 & $\begin{array}{l}\text { Safeek } \\
\text { et al. } \\
(2018)^{51}\end{array}$ & $\begin{array}{l}\text { Low levels of physical activity } \\
\text { among older persons living with } \\
\text { HIVIAIDS are associated with } \\
\text { poor physical function. }\end{array}$ & $\begin{array}{l}\text { Quasi- } \\
\text { experimental } \\
\text { design }\end{array}$ & $\begin{array}{l}\text { United } \\
\text { States of } \\
\text { America } \\
\text { (Urban) }\end{array}$ & $N=21$ & $\begin{array}{l}\text { Greater physical activity was associated with better } \\
\text { physical performance, while more sedentary time was } \\
\text { associated with poorer performance. Older people } \\
\text { living with HIV fall far short of public health guidelines } \\
\text { for promoting physical activity participation. }\end{array}$ \\
\hline 10 & $\begin{array}{l}\text { Cioe et al. } \\
(2019)^{52}\end{array}$ & $\begin{array}{l}\text { The effect of increased physical } \\
\text { activity on symptom burden in } \\
\text { older persons living with HIV. }\end{array}$ & $\begin{array}{l}\text { Quasi- } \\
\text { experimental } \\
\text { design }\end{array}$ & $\begin{array}{l}\text { United } \\
\text { States of } \\
\text { America } \\
\text { (Urban) }\end{array}$ & $N=40$ & $\begin{array}{l}\text { Increased PA was not associated with an improvement } \\
\text { in overall HIV symptom burden. However, bothersome } \\
\text { symptoms were reduced, and total symptom burden } \\
\text { was strongly correlated with PA after } 12 \text { weeks, such } \\
\text { that participants who had higher step counts reported } \\
\text { lower symptom burden. Significant gender differences } \\
\text { in symptom burden were noted, with males, on average, } \\
\text { reporting lower symptom burden. }\end{array}$ \\
\hline 11 & $\begin{array}{l}\text { De Layna } \\
\text { Goulding } \\
\text { et al. } \\
(2019)^{53}\end{array}$ & $\begin{array}{l}\text { A supervised exercise } \\
\text { intervention fails to improve } \\
\text { depressive symptoms and quality } \\
\text { of life among older, sedentary } \\
\text { adults with HIV infection. }\end{array}$ & $\begin{array}{l}\text { Randomized } \\
\text { control trial }\end{array}$ & $\begin{array}{l}\text { United } \\
\text { States of } \\
\text { America } \\
\text { (Urban) }\end{array}$ & $\begin{array}{l}\mathrm{N}=69 \text { (PLWH=32, } \\
\text { uninfected; } \\
\text { control=37) }\end{array}$ & $\begin{array}{l}\text { No significant improvements in most mental health } \\
\text { outcomes over } 24 \text { weeks of supervised aerobic and } \\
\text { resistance exercise. }\end{array}$ \\
\hline 12 & $\begin{array}{l}\text { Johs et al. } \\
(2019)^{54}\end{array}$ & $\begin{array}{l}\text { A qualitative focus group study } \\
\text { of perceived barriers and } \\
\text { benefits to exercise by self- } \\
\text { described exercise status among } \\
\text { older adults living with HIV. }\end{array}$ & $\begin{array}{l}\text { Focus group } \\
\text { discussion }\end{array}$ & $\begin{array}{l}\text { United } \\
\text { States of } \\
\text { America } \\
\text { (Urban) }\end{array}$ & $\begin{array}{l}N=29 \text { exercising } \\
\text { men }(n=11) \text {, non- } \\
\text { exercising men } \\
(n=14) \text {; women (non- } \\
\text { exercisers and } \\
\text { exercisers, } n=4)\end{array}$ & $\begin{array}{l}\text { Exercisers emphasized positive reinforcement, positive } \\
\text { mood change and increased energy as benefits of } \\
\text { exercise. Non-exercisers identified lack of motivation, } \\
\text { lack of self-efficacy and a negative perception of gym } \\
\text { culture as barriers to exercise. Both groups identified } \\
\text { time, cost and health-related challenges as barriers to } \\
\text { exercise. }\end{array}$ \\
\hline 13 & $\begin{array}{l}\text { Webel } \\
\text { et al. } \\
(2019)^{55}\end{array}$ & $\begin{array}{l}\text { The relationship between } \\
\text { physical activity and } \\
\text { cardiorespiratory fitness among } \\
\text { people living with human } \\
\text { immunodeficiency virus } \\
\text { throughout their life spans }\end{array}$ & $\begin{array}{l}\text { Cross- } \\
\text { sectional } \\
\text { study }\end{array}$ & $\begin{array}{l}\text { United } \\
\text { States of } \\
\text { America } \\
\& \\
\text { Thailand } \\
\text { (Urban) }\end{array}$ & $N=702$ & $\begin{array}{l}\text { Weekly physical activity of people living with HIV } \\
\text { averaged well below the recommended level of } \\
\text { moderate activity. Vigorous physical activity was } \\
\text { associated with improved cardiorespiratory fitness in } \\
\text { women, but not men. }\end{array}$ \\
\hline 14 & $\begin{array}{l}\text { Chung } \\
\text { and Louw } \\
(2020)^{56}\end{array}$ & $\begin{array}{l}\text { Effects of supervised exercise on } \\
\text { physical health and quality of life } \\
\text { among older adults living with } \\
\text { HIV in Hong Kong. }\end{array}$ & $\begin{array}{l}\text { Randomized } \\
\text { control trial }\end{array}$ & $\begin{array}{l}\text { China } \\
\text { (Urban) }\end{array}$ & $\begin{array}{l}\mathrm{N}=2 \mathrm{I}(\text { Control }=10, \\
\text { Intervention }=\mathrm{I} \mathrm{I})\end{array}$ & $\begin{array}{l}\text { An eight-week, moderate-intensity, supervised exercise } \\
\text { intervention was feasible for older Chinese PLWH. It } \\
\text { improved physical health and aspects of health-related } \\
\text { quality of life. The moderate-intensity training was well } \\
\text { tolerated by participants with an inactive lifestyle. } \\
\text { Participants in the exercise group showed excellent } \\
\text { exercise adherence. }\end{array}$ \\
\hline 15 & $\begin{array}{l}\text { Stabell } \\
\text { et al. } \\
(2020)^{57}\end{array}$ & $\begin{array}{l}\text { The impact of a structured, } \\
\text { supervised exercise programme } \\
\text { on daily step count in older, } \\
\text { sedentary adults with and } \\
\text { without HIV. }\end{array}$ & $\begin{array}{l}\text { Randomized } \\
\text { control trial }\end{array}$ & $\begin{array}{l}\text { United } \\
\text { States of } \\
\text { America } \\
\text { (Urban) }\end{array}$ & $\begin{array}{l}\mathrm{N}=38 \text { (Control=17, } \\
\text { Intervention }=2 \mathrm{I} \text { ) }\end{array}$ & $\begin{array}{l}\text { Supervised exercise increased daily step counts in } \\
\text { sedentary individuals, but at the expense of fewer steps } \\
\text { on non-supervised exercise days. }\end{array}$ \\
\hline
\end{tabular}


literature. No studies reported any adverse side effects, or any safety and efficacy concerns, during the use of aerobic exercise, resistance exercise, or both for this population

\section{Exercise and Psychological Health}

Just four out of the fifteen selected articles focused on the effects of exercise on mental health $(4,5,6$, and 11). Further interrogation of these articles revealed that only Goulding et al (2019) (11) failed to show any significant improvements in mental health outcomes. Some of the reasons cited by the authors for the lack of improvement include the significant burden of mental illness already present in the sample population (nearly $25 \%$ in the control group and $>50 \%$ in the intervention group). Other contributing factors were the duration of the intervention used in this study in comparison to the other studies (24 weeks versus 12 weeks or less) and the assigned increase in exercise intensity in the second half (12 weeks) of the study. Shah et al (2016) (5) reported significant improvements in measurements of depression following a twelveweek exercise intervention. Fazeli et al (2015) (4) suggest that physical activity is associated with improved neurocognitive functioning in this population. The authors further advocate for moderate physical activity as the optimal level for positive neurological outcomes in OPLWH. Preliminary data reported by Veeravelli et al (2016) (6) suggests that participation in a virtual-realitybased exercise intervention programme, just twice a week for six weeks, has the potential to alleviate depression and frailty in OPLWH.

\section{Exercise and Quality of Life (QoL)}

Seven of the fifteen articles also discussed some aspect of the effects of exercise on the quality of life (QoL) of OLPWH (3, 4, 5, 6, 10, 11, and 14). Four of these studies made use of the Short Form Health Survey (36-item and 12-item) questionnaire to evaluate participants' perception of QoL (5, 6, 11, and 14). De Araújo et al (2014) (3) and Fazeli et al (2015) (4) utilized the Quality of Life Assessment HIV (WHOQOL-HIV-Bref) tool and the Lawton and Brody Activity of Daily Living Questionnaire, respectively. Cioe et al (2019) (10) used no particular QoL measurement tool but did manage to report reduced overall symptom burden and fatigue levels with increasing levels of physical activity. All but one (11) of the seven studies showed an improvement in overall QoL measurements following exercise intervention in OPLWH. However, the authors reported that many participants expressed study-visit and intervention fatigue following the twenty-four weeks of the intervention, which could have reflected in their final QoL and mood scores. The authors further suggested that OPLWH may need additional interventions to maintain motivation, limit fatigue and enhance QoL improvements. Some of the suggestions included prescribing a greater variety of exercise, motivational interviewing and goalsetting, or adjuvant therapies such as yoga and massage.

\section{Discussion}

Analysis of the selected studies suggests that performing aerobic exercise, or a combination of constant aerobic and progressive resistance training, appears to be safe and may lead to significant improvements in measurements of cardiorespiratory fitness $\left(\mathrm{VO}^{2} \max \right)$, strength and psychological outcomes (mental health and QoL) in OPLWH. Results for cardiorespiratory status indicated improvements in $\mathrm{VO}^{2}$ max measurements in aerobic exercise participants compared to non-exercise participants. Similar improvements were also observed in combined aerobic and resistance exercisers, compared with their non-exercising counterparts; while even greater improvements were noticed among participants doing high rather than moderate intensity exercise. The results of this review suggest that aerobic exercise, resistance training, or a combination of both, appears to be safe for OPLWH. None of the studies reported any serious adverse events, health problems or complications during physical activity. However, this finding should be interpreted cautiously as the results in most of the studies are based on participants who have completed the exercise intervention and for whom adequate follow-up data does exist. Further evidence in the literature noted that structured exercise programmes may be an initial motivator to increase activity levels in this population. The accountability of OPLWH regarding supervised exercise can increase exercise adherence, which in turn can improve physical function; and these benefits are more likely to continue even after an intervention has ended.

Combined aerobic and progressive resistance training effected significant improvements in upper and lower body strength, as well as in measurements of balance, flexibility and ambulatory function; while greater improvements in strength were observed only in resistance exercise participants, compared to their aerobic exercising counterparts. This suggests that combined aerobic and resistance training may be ideal to maximize both the cardiovascular and 
strength benefits of exercise. A similar trend was reported by Yahiaoui and colleagues when developing evidencebased exercise recommendations for HIV populations. ${ }^{1}$

Results for psychological status demonstrated significant improvements in depressive symptoms and overall QoL, as well as better neurocognitive and everyday functioning among OPLWH who exercise. The neurocognitive domain of executive functioning might benefit the most from physical activity and exercise. This is consistent with similar studies undertaken with non-HIV aging people. ${ }^{40}$ Significant improvements were observed in the QoL domain parameters for physical functioning; role limitations due to physical health; emotional well-being; social functioning; and general health. The benefits of physical activity and exercise on mental health, neurocognitive outcomes, and activities of daily living within adult HIV populations are extensive. ${ }^{41-43}$ This review is similar and consistent with these findings.

Finally, in this review, the most commonly reported length of time and frequency of exercise ranged from two to twenty-four weeks and two to three times per week, respectively. There is consensus that, in general, it can be safe and beneficial for HIV populations to exercise (aerobic or a combination of aerobic and resistance) for 20 minutes, three times per week, for at least five weeks. ${ }^{27}$ The length of time and frequency of exercise for OPLWH does, however, require further investigation.

\section{Limitations}

This scoping review applied a systematic and rigorous search strategy that retrieved several articles to answer our research questions and objectives. As our topic focused on physical activity and exercise in the context of OPLWH, well-known electronic databases were used as primary sources. Each element from the PPC framework was searched with multiple keywords in order to target all relevant studies. However, we may have omitted some relevant studies published in other languages by only including articles published in English. This was done to prevent possible bias when attempting to accurately represent evidence published in languages other than the lead author's first language. Additionally, we only considered peer-reviewed articles without assessing the existing evidence in the grey literature. The non-consideration of the grey literature restricts our findings to what was reported by scientific journals and possibly prevented the analysis of relevant cases that were rejected for publication by scientific editors.

\section{Conclusion}

To our knowledge this is the first review that systematically describes evidence-based, published research that explores the intersection between prescribed exercise interventions and OPLWH. What is immediately noticeable is the relatively low number of published research papers on physical activity and its effects on OPLWH, with just two of the selected studies using a simple case study design. The effects on psychological health also yielded a low return of just four articles. The physical, psychological and QoL impact of physical activity and its effect on OPLWH is evidently beneficial. The results from the selected studies reflect a clinically significant improvement in physical functioning, psychological health and overall health-related QoL, compared to nonexercisers. However, the question arises as to why there is so little research available on physical activity or exercise interventions for OPLWH, especially in resource-poor settings. The authors noted that only three out of the fifteen selected studies were conducted in the developing world. Of greater concern is the fact that there were no studies conducted in sub-Saharan Africa, the global region with by far the highest HIV burden. It is vital, therefore, that evidence in this field focuses on the specific challenges faced by OPLWH in resource-poor African countries. With increased life expectancy in both the developed and developing world, it is crucial that a range of alternative rehabilitation options, including physical activity and exercise, be made available to OPLWH. This scoping review indicates that physical activity and exercise is a promising approach that is both an effective and safe treatment option for OPLHIV. It can confer a number of physical, psychological and QoL benefits on participants in these programmes.

\section{Recommendations}

This review confirms the dearth of evidence on physical activity and exercise in the context of OPLWH. Further research on physical activity and exercise for OPLWH is urgently needed to inform the design and implementation of improved rehabilitation options for OPLWH. Research is also necessary to develop recommendations relating to the parameters of frequency, intensity, time and type of exercise that may be most beneficial to OPLWH. Researchers in this field need to go beyond the medical paradigm and seek to demonstrate the holistic benefits that physical activity and 
exercise can provide to OPLWH. Studies should also involve a wide range of assessment measurements, such as tools that investigate OPLWHs' full participation in activities of daily living, and the cost-effectiveness of physical activity and exercise interventions. To this effect, the use of larger multidisciplinary studies that better reflect the challenges faced by OPLWH should never be understated. This would not only assist greatly in ensuring that OPLWH have the beneficial physical, psychological and QoL opportunities to match the added years of life made possible through the advances in medical technology, but also provide another weapon in the arsenal that can be included in the development of comprehensive management and care options for older HIV populations.

\section{Acknowledgments}

The authors would like to express our gratitude to the South African Medical Research Council (SAMRC) for their ongoing support of our research endeavors. Research reported in this study was supported by the SAMRC under a Self-Initiated Research Grant and the Bongani Mayosi National Health Scholars Programme. The views and opinions expressed are those of the author(s) and do not necessarily represent the official views of the SAMRC.

\section{Disclosure}

The authors declared no potential conflicts of interest with respect to the research, authorship, and/or publication of this article.

\section{References}

1. Yahiaoui A, McGough EL, Voss JG. Development of Evidence-Based Exercise Recommendations for Older HIV-Infected Patients. $J$ Assoc Nurses AIDS Care. 2012;23(3):204-219. doi:10.1016/j.jana.20 11.06 .001

2. Grov C, Golub SA, Parsons JT, Brennan M, Karpiak SE. Loneliness and HIV-related stigma explain depression among older HIV-positive adults. AIDS Care. 2010;22(5):630-639. doi:10.1080/09540120 903280901

3. Hogg R, Lima V, Sterne JA. Antiretroviral therapy cohort collaboration: life expectancy of individuals on combination antiretroviral therapy in high-income countries: a collaborative analysis of 14 cohort studies. Lancet. 2008;372:293-9. doi:10.1016/S0140-6736(08)61113-7

4. Mills EJ, Bñrnighausen T, Negin J. HIV and aging - preparing for the challenges ahead. $N$ Engl $J$ Med. 2012;366(14):1270-1273. doi:10.1056/NEJMp1113643

5. Smit M, Brinkman K, Geerlings S, et al. Future challenges for clinical care of an ageing population infected with HIV: a modelling study. Lancet Infect Dis. 2015;15(7):810-818. doi:10.1016/S1473-3099(15) 00056-0

6. Hontelez JAC, De Vlas SJ, Baltussen R, et al. The impact of antiretroviral treatment on the age composition of the HIV epidemic in sub-Saharan Africa. AIDS. 2012;26:S19-S30. doi:10.1097/ QAD.0b013e3283558526
7. Oursler KK, Tate JP, Gill TM, et al. Association of the Veterans Aging Cohort Study Index with Exercise Capacity in HIV-Infected Adults. AIDS Res Hum Retroviruses. 2013;29(9):130626063834008. doi:10.1089/aid.2012.0388

8. Kahn K, Tollman S, Thorogood M, et al. Aging in Sub-Saharan Africa. Recommendations for Furthering Research National Academies Press: Washington DC; 2006. doi:10.17226/11708

9. Ortiz A. Exercise for Adults Living with Human Immunodeficiency Virus Infection in the Era of Highly Active Antiretroviral Therapy. Int $J$ Phys Med Rehabil. 2014;02(04):1-4. doi:10.4172/23299096.1000213

10. O'Brien KK, Tynan AM, Nixon SA, Glazier RH. Effectiveness of Progressive Resistive Exercise (PRE) in the context of HIV: systematic review and meta-analysis using the Cochrane Collaboration protocol. BMC Infect Dis. 2017;17. doi:10.1186/ s12879-017-2342-8.

11. Nideröst S, Imhof C. Aging With HIV in the Era of Antiretroviral Treatment. Gerontol Geriatr Med. 2016;2:233372141663630. doi: $10.1177 / 2333721416636300$

12. Effros RB, Fletcher CV, Gebo K, et al. Aging and Infectious Diseases: workshop on HIV Infection and Aging: what Is Known and Future Research Directions. Clin Infect Dis. 2008;47(4):542-553. doi: $10.1086 / 590150$

13. Althoff KN, Smit M, Reiss P, Justice AC. HIV and ageing: improving quantity and quality of life. Curr Opin HIV AIDS. 2016;11 (5):527-536. doi:10.1097/COH.0000000000000305

14. Erlandson KM, Allshouse AA, Jankowski CM, MaWhinney S, Kohrt WM, Campbell TB. Functional impairment is associated with low bone and muscle mass among persons aging with HIV infection. J Acquir Immune Defic Syndr. 2013;63(2):209-215. doi:10.1097/ QAI.0b013e318289bb7e

15. Erlandson K, Allshouse A, Jankowski C, et al. Comparison of functional status instruments in HIV-infected adults on effective antiretroviral therapy. HIV Clin Trials. 2012;13(6):324-334. doi:10.1310/ hct1306-324

16. Orlando M, Burnam MA, Beckman R, et al. Re-estimating the prevalence of psychiatric disorders in a nationally representative sample of persons receiving care for HIV: results from the HIV cost and services utilization study. Int $J$ Methods Psychiatr Res. 2002;11:75-82. doi:10.1002/mpr.125

17. Penzak SR, Reddy YS, Grimsley SR. Depression in patients with HIV infection. Am J Heal Pharm. 2000;57(4):376-386. doi:10.1093/ ajhp/57.4.376

18. Ibeneme SC, Irem FO, Iloanusi NI, et al. Impact of physical exercises on immune function, bone mineral density, and quality of life in people living with HIV/AIDS: a systematic review with meta-analysis. BMC Infect Dis. 2019;19(1):1-18. doi:10.1186/ s12879-019-3916-4

19. Oliveira VHF, Rosa FT, Santos JC, et al. Effects of a Combined Exercise Training Program on Health Indicators and Quality of Life of People Living with HIV: a Randomized Clinical Trial. AIDS Behav. 2019. doi:10.1007/s10461-019-02678-3

20. Jeon CY, Lokken RP, Hu FB, Van Dam RM. Physical activity of moderate intensity and risk of type 2 diabetes: a systematic review. Diabetes Care. 2007;30(3):744-752. doi:10.2337/dc06-1842

21. Sparling PB, Howard BJ, Dunstan DW, Owen N. Recommendations for physical activity in older adults. BMJ. 2015;350:h100-h100. doi:10.1002/app. 25566

22. Vogel T, Brechat PH, Leprêtre PM, Kaltenbach G, Berthel M, Lonsdorfer J. Health benefits of physical activity in older patients: a review. Int J Clin Pract. 2009;63:303-320. doi:10.1111/j.17421241.2008.01957.x

23. Bird ML, Hill K, Ball M, Williams AD. Effects of resistance- and flexibility-exercise interventions on balance and related measures in older adults. J Aging Phys Act. 2009;17:444-454. doi:10.1123/ japa.17.4.444 
24. Jordan LY, Melanson EL, Melby CL, Hickey MS, Miller BF. Nitrogen balance in older individuals in energy balance depends on timing of protein intake. J Gerontol. 2010;65A(10):1068-1076. doi:10.1093/gerona/glq123

25. Roma MFB, Busse AL, Betoni RA, et al. Effects of resistance training and aerobic exercise in elderly people concerning physical fitness and ability: a prospective clinical trial. Einstein. 2013;11:153-157. doi:10.1590/S1679-45082013000200003

26. Chetty L, Ramklass SS, McKune AJ. The effects of a structured group exercise programme on functional fitness of older persons living in old-age homes. Ageing Soc. 2019;39(9):1857-1872. doi:10.1017/S0144686X18000235

27. Brien KKO, Tynan A, Nixon SA, Glazier RH, O’Brien K. Effectiveness of Aerobic Exercise for Adults Living with HIV: systematic Review and Meta-Analysis Using the Cochrane Collaboration Protocol. BMC Infect Dis. 2016. doi:10.1186/s12879-016-1478-2

28. Aweto HA, Aiyegbusi AI, Ugonabo AJ, Adeyemo TA. Effects of Aerobic Exercise on the Pulmonary Functions, Respiratory Symptoms and Psychological Status of People Living With HIV.J Res Health Sci. 2016;16(1):17-21. doi:10.1016/0003-9861(81)90347-7

29. Zanetti HR, da Cruz LG, Lourenço CLM, et al. Nonlinear Resistance Training Enhances the Lipid Profile and Reduces Inflammation Marker in People Living With HIV: a Randomized Clinical Trial. J Phys Act Heal. 2016;13:765-770. doi:10.1123/jpah.2015-0540

30. Dufour CA, Marquine MJ, Fazeli PL, et al. A Longitudinal Analysis of the Impact of Physical Activity on Neurocognitive Functioning Among HIV-Infected Adults. AIDS Behav. 2018;22(5):1562-1572. doi:10.1007/s10461-016-1643-z

31. Fazeli PL, Marquine MJ, Dufour C, et al. Physical Activity is Associated with Better Neurocognitive and Everyday Functioning Among Older Adults with HIV Disease. AIDS Behav. 2015;19 (8):1470-1477. doi:10.1007/s10461-015-1024-z

32. Hand GA, Lyerly GW, Jaggers JR, Dudgeon WD. Impact of Aerobic and Resistance Exercise on the Health of HIV-Infected Persons. Am J Lifestyle Med. 2009;3(6):489-499. doi:10.1177/1559827609342198

33. Mutimura E, Stewart A, Crowther NJ, Yarasheski KE, Cade WT. The effects of exercise training on quality of life in HAART-treated HIV-positive Rwandan subjects with body fat redistribution. Qual Life Res. 2008;17(3):377-385. doi:10.1007/s11136-008-9319-4

34. Grace JM, Semple SJ, Combrink S. Exercise therapy for human immunodeficiency virus/AIDS patients: guidelines for clinical exercise therapists. J Exerc Sci Fit. 2015;13(1):49-56. doi:10.1016/j. jesf.2014.10.003

35. American Collegue of Sports Medicine. ACSM's Guidelines for Exercise Testing and Prescription (10th Edition); 2016. doi:10.1017/CBO9781107415324.004

36. Arksey H, O’Malley L. Scoping studies: towards a methodological framework. Int J Soc Res Methodol Theory Pract. 2005;8(1):19-32. doi:10.1080/1364557032000119616

37. Chetty L, Cobbing S, Chetty V. Physical activity and exercise for older people living with HIV: a protocol for a scoping review. Syst Rev. 2020;9(1). doi:10.1186/s13643-020-01327-4

38. The Joanna Briggs Institute. Methodology for JBI Scoping Reviews. Reviewers' Manual. Joanna Briggs Inst. 2015. doi:10.1017/ CBO9781107415324.004

39. Hong QN, Gonzalez-Reyes A, Pluye P. Improving the usefulness of a tool for appraising the quality of qualitative, quantitative and mixed methods studies, the Mixed Methods Appraisal Tool (MMAT). J Eval Clin Pract. 2018;24:459-467. doi:10.1111/jep.12884

40. Colcombe S, Kramer AF. Fitness effects on the cognitive function of older adults: a meta-analytic study. Psychol Sci. 2003;14(2):125-130. doi:10.1111/1467-9280.t01-1-01430
41. Gomes Neto M, Ogalha C, Andrade AM, Brites C. A systematic review of effects of concurrent strength and endurance training on the health-related quality of life and cardiopulmonary status in patients with HIV/AIDS. Biomed Res Int. 2013;2013:1-8. doi:10.1155/2013/ 319524

42. Gomes-Neto M, Conceição CS, Carvalho VO, Brites C. A systematic review of the effects of different types of therapeutic exercise on physiologic and functional measurements in patients with HIV/AIDS. Clinics. 2013;68(8):1157-1167. doi:10.6061/clinics/2013(08)16

43. Fillipas S, Cherry CL, Cicuttini F, Smirneos L, Holland AE. The effects of exercise training on metabolic and morphological outcomes for people living with HIV: a systematic review of randomised controlled trials. HIV Clin Trials. 2010;11(5):270-282. doi:10.1310/ het1105-270

44. de Souza PML, Filho WJ, Santarém JM, et al. Progressive resistance training on elderly HIV+patients: does it work? Am J Infect Dis. 2008. doi:10.3844/ajidsp.2008.215.219

45. de Souza PML, Jacob-Filho W, Santarém JM, Zomignan AA, Burattini MN. Effect of progressive resistance exercise on strength evolution of elderly patients living with HIV compared to healthy controls. Clinics. 2011;66(2):261-266. doi:10.1590/S180759322011000200014

46. De Araújo APS, Gouvêa JAG, Martins Junior J, Bertolini DA, Bertoline SMMG. Influence of physical exercise on practice standards morphofunctional, immune function and quality of elderly with aids: case study. Man Ther Posturology Rehabil J. 2014;12(44):176. doi:10.17784/mtprehabjournal.2014.12.176

47. Shah KN, Majeed Z, Yoruk YB, et al. Enhancing physical function in HIV-infected older adults - a randomised controlled clinical trial. Health Psychology: Official Journal of the Division of Health Psychology, American Psychological Association. 2016;35 (6):563-573. doi:10.1037/hea0000311.ADULTS

48. Veeravelli S, Najafi B, Marin I, Blumenkron F, Smith S, Klotz SA. Exergaming in older people living with HIV improves balance, mobility and ameliorates some aspects of frailty. $J$ Vis Exp. 2016;2016(116):1-9. doi:10.3791/54275

49. Erlandson KM, Mawhinney S, Wilson M, et al. Physical function improvements with moderate or high-intensity exercise among older adults with or without HIV infection. AIDS. 2018;32(16):2317-2326. doi:10.1097/QAD.0000000000001984

50. Oursler KK, Sorkin JD, Ryan AS, Katzel LI. A pilot randomized aerobic exercise trial in older HIV-infected men: insights into strategies for successful aging with HIV. PLoS One. 2018;13(6):1-12. doi:10.1371/journal.pone.0198855

51. Safeek RH, Hall KS, Lobelo F, et al. Low Levels of Physical Activity Among Older Persons Living with HIV/AIDS Are Associated with Poor Physical Function. AIDS Res Hum Retroviruses. 2018;34 (11):929-935. doi:10.1089/aid.2017.0309

52. Cioe PA, Gordon REF, Williams DM, Kahler CW. The effect of increased physical activity on symptom burden in older persons living with HIV. AIDS Care Psychol Socio Med Asp AIDS/HIV. 2019;31(12):1548-1554. doi:10.1080/09540121.2019.1601675

53. Goulding DL, Wilson MP, MaWhinney S, Jankowski CM, Erlandson KM. A supervised exercise intervention fails to improve depressive symptoms and quality of life among sedentary older adults with HIV infection. AIDS Care Psychol Socio Med Asp AIDS/HIV. 2020;32(6):714-721. doi:10.1080/09540121.2019.1634788

54. Johs NA, Kellar-Guenther Y, Jankowski CM, Neff H, Erlandson KM. A qualitative focus group study of perceived barriers and benefits to exercise by self-described exercise status among older adults living with HIV. BMJ Open. 2019;9(3):e026294. doi:10.1136/bmjopen2018-026294 
55. Webel AR, Perazzo J, Phillips JC, et al. The Relationship between Physical Activity and Cardiorespiratory Fitness among People Living with Human Immunodeficiency Virus throughout the Life Span. $J$ Cardiovasc Nurs. 2019;34(5):364-371. doi:10.1097/JCN.000000 0000000589

56. Chung CH, Lou VWQ. Effects of Supervised Exercise on Physical Health and Quality of Life Among Older Adults Living With HIV in Hong Kong. J Assoc Nurses AIDS Care. 2020;31(3):353-358. doi:10.1097/JNC.0000000000000099
57. Stabell AC, Wilson M, Jankowski CM, MaWhinney S, Erlandson KM. The Impact of a Structured, Supervised Exercise Program on Daily Step Count in Sedentary Older Adults With and Without HIV. J Acquir Immune Defic Syndr. 2020;84(2):228-233. doi:10.1097/QAI.0000000000002326

58. Moher D, Liberati A, Altman D, Tetzlaff J, et al. The PRISMA statement for reporting systematic reviews and meta-analyses of studies that evaluate health care interventions: explanation and elaboration. Journal of clinical epidemiology. 2009;62(10).

\section{Publish your work in this journal}

HIV/AIDS - Research and Palliative Care is an international, peerreviewed open-access journal focusing on advances in research in HIV, its clinical progression and management options including antiviral treatment, palliative care and public healthcare policies to control viral spread. The manuscript management system is completely online and includes a very quick and fair peer-review system, which is all easy to use. Visit http://www.dovepress.com/testimonials.php to read real quotes from published authors. 